\title{
IMPLEMENTASI KURIKULUM ANAK BERKEBUTUHAN KHUSUS DI LENTERA HATI SCHOOL KUDUS
}

\author{
Rukhaini Fitri Rahmawati \\ Institut Agama Islam Negeri Kudus \\ rukhaini@stainkudus.ac.id
}

\begin{abstract}
Abstrak
Berawal dari banyaknya permasalahan tentang kurikulum tanpa terkecuali kurikulum bagi anak berkebutuhan khusus. Sebagai contoh permasalahan kurikulum bagi anak ABK di sekolah inklusi yang masih belum dapat teraplikasikan dengan baik karena kurangnya penguasaan SDM terhadap kurikulum itu sendiri. Penelitian ini bertujuan untuk mengetahui bagaimana implementasi kurikulum anak berkebutuhan khusus yang ada di Lentera Hati School serta apa saja faktor pendukung dan penghambatnya dalam pelaksanaan implementasi kurikulum tersebut. penelitian ini merupakan penelitian lapangan (field research) dengan menggunakan pendekatan kualitatif deskriptif analitik. Hasil dari penelitian ini yaitu: implementasi kurikulum di Lentera Hati School dimulai dari perencanaan kurikulum yang tertuang dalam RPPM, dan RPPH yang mengacu pada kurikulum 2013 PAUD yang kemudian dimodifikasi dengan merunkan standar capaian pembelajaran disesuaikan dengan kebutuhan dan kemampuan peserta didik. Pengklasifikasian anak didasarkan pada mental age dan kemampuan didik anak. RPPH dirancang sefleksibel mungkin karena kelas bersifat heterogen. Kegiatan Inti pembelajaran mengacu pada pengembangan Nilai Agama dan Moral, Fisik Motorik, Kognitif, Bahasa, Sosial Emosi, Seni dan Kreatifitas. Media pembelajaran yang digunakan mengedepanan prinsip efektif dan efisien serta aman bagi para peserta didik. Sistem penilaian didasarkan pada penilaian oleh guru dan hasil terapi.
\end{abstract}

Kata Kunci: Kurikulum, Anak Berkebutuhan Khusus, Pendidikan Anak Usia Dini.

\begin{abstract}
There are so many problems about curriculum, including the curriculum for children with special needs. For example, curriculum in inclusive schools cannot be applied properly due to the lack of human resources mastery on the curriculum itself. This study aims to find out how the implementation of curriculum for children with special needs in Lentera Hati School and what are the supporting factors and obstacles in implementing the curriculum. This research was field research that used a descriptive analytic qualitative approach.The results of this study are: the implementation of the curriculum at Lentera Hati School includes curriculum planning described in RPPM and RPPH which refers to the 2013 PAUD curriculum which is then modified by decreasing the learning achievement standards according to the students' needs and abilities. Child classification is based on the student's mental age and ability. RPPH is designed as flexible as possible because classes are heterogeneous. The core activities of learning refer to the development of Religious and Moral Values, Motoric Physical, Cognitive, Language, Social Emotions, Art and Creativity. Learning media are used to prioritize the effective and efficient and safe principles for students. The scoring system is based on assessment from the teacher and the results of therapy.

Keywords: Curriculum, Children with Special Needs, Early Childhood Education.
\end{abstract}




\section{A. Pendahuluan}

Fitrah dari setiap anak yaitu terlahir dengan karakteristik, bakat, kelebihan dan kekurangan masing-masing. Selalu istimewa, unik dan berbeda antara setiap individu. Termasuk anak yang terlahir dengan berkebutuhan khusus baik secara fisik maupun psikisnya. Anak berkebutuhan khusus yang selanjutnya disebut ABK, merupakan anak yang mempunyai kekhususan baik pada sensori atau fisik, komunikasi, kognisi, perkembangan tingkah laku, emosional, dan sosial. Karena kekhususannya, maka ABK juga memerlukan penangan yang khusus atau berbeda dengan anak-anak pada umumnya termasuk pada aspek pendidikannya.

Pendidikan khusus bagi para ABK dimaksudkan agar porsi pendidikan yang diberikan sesuai dengan kebutuhan dan kemampuan mereka dalam melakukan proses pembelajaran. Dalam Undang-Undang NO 20 Tahun 2003 tentang Sistem Pendidikan Nasional pasal 32 ayat 1 disebutkan bahwa pendidikan khusus merupakan pendidikan bagi peserta didik yang memiliki tingkat kesulitan dalam mengikuti proses pembelelajaran karena kelainan fisik, emosional, mental, social, dan/atau memiliki potensi kecerdasan dan bakat istimewa. Hal selaras juga tertuang pada Permendikbud nomor 157 tahun 2014 tentang kurikulum pendidikan khusus.

Langkah nyata pemerintah dalam memberikan pendidikan khusus diwujudkan dengan adanya sekolah luar biasa (SLB) yang dilengkapi dengan seperangkat kurikulum khusus ABK. Konsep sekolah inklusi juga ditawarkan bagi para peserta didik $\mathrm{ABK}$ yang menginginkan pendidikan regular. Hal tersebut membantu para $\mathrm{ABK}$ untuk dapat mengenyam pendidikan yang setara dengan anak-anak pada umumnya. Sehingga kehadiran anak ABK dapat diterima di tengah-tengah masyarakat dan tidak lagi termarginalkan. Meski demikian, banyak dari lembaga dan masyarakat yang belum siap akan hadirnya pendidikan inklusi tersebut. Karena untuk melaksanakan pendidikan inklusi, sekolah harus memiliki unsur-unsur pokok seperti kurikulum $\mathrm{ABK}$, SDM, dan fasilitas lain sebagainya yang mendukung, agar pendidikan regular dan inklusi dapat dilaksanakan bersama-sama dalam satu atap.

Permasalahan tersebut yang menjadikan beberapa sekolah inklusi termasuk salah satu sekolah inklusi di kabupaten Kudus memutuskan untuk tidak lagi menjadi sekolah inklusi. Hal tersebut juga menjadi salah satu alasan 
para wali siswa tetap atau lebih memilih SLB daripada sekolah inklusi. Berdasarkan hasil evaluasi pada sekolah inklusi di provinsi Jawa Tengah, menunjukkan bahwa pelaksanaan pendidikan inklusi di Jawa Tengah masih dinilai kurang, terlebih pada kurkulumnya. Hal ini disebabkan karena kurikulum yang digunakan belum dimodifikasi pada tataran rancangan perangkat pembelajaran baik silabus, RPP, dan evaluasi. Termasuk didalamnya program khusus pengembangan diri(Haryono, 2015, pp. 124125).

Kesadaran akan kebutuhan pendidikan bagi anak berkebutuhan khusus menjadikan banyak yayasan atau lembaga pendidikan swasta mendirikan sekolah khusu untuk anak ABK. Bukan hanya pendidikan yang ditawarkan, namun program khusus seperti pengembangan diri, kegiatan keagamaan hingga terapi penyembuhan. Program- program khusus tersebut lah yang menjadi harapan dan optimisme bagi para orang tua yang mengharapkan anaknya yang istimewa dapat mengembangakan kemandirian, social hingga kesembuhan. Karena ABK yang berada pada tingkat tertentu seperti autis dan gangguan belajar ringan lainnya dapat disembuhkan, tentunya dengan terapi penyembuhan.

Yayasan Lentera Hati merupakan salah satu yayasan social di Kudus yang mempunyai kepedulian terhadap ABK. Yayasan ini mendirikan Lentera Hati School, sebuah sekolah anak berkebutuhan khusus bagi anak pra sekolah, sekolah dasar, dan day care. Program unggulan dari sekolah ABK ini adalalah mengaji $\mathrm{ABK}$, ketrampilan bina diri $\mathrm{ABK}$, dan pengembangan bakat $\mathrm{ABK}$. Yayasan Lentera Hati didirikan oleh Ibu Myke yang merupakan seorang psikolog sekaligus terapis, sehingga kurikulum yang digunakan adalah kurikulum adaptif yang diadaptasi dari SLB yang kemudian juga dipadukan dengan terapi. Perpaduan tersebut memberikan dampak yang sangat signifikan bagi kemajuan pembelajaran dan penyembuhan ABK. Hal tersebut dibuktikan dengan adanya salah satu murid dari Lentera Hati School yang berpindah ke sekolah regular karena telah dianggap sembuh dan mampu menyesuaikan diri dengan anak-anak pada umumnya.

Pengembangan kurikulum yang dilakukan oleh Lentera Hati School bagi peneliti sangat menarik, melihat bahwa pendidikan yang dilakukan disana 
tidak hanya menitik beratkan pada kemampuan kognitif seperti calistung (baca. tulis, hitung) serta pegembangan diri saja. Lebih dari itu program terapi yang ditawarkan menjadikan ABK mampu melakukan pencapaian pengembangan diri lebih baik lagi. Konsep pendidikan yang dikombinasikan dengan terapi atau penyembuhan menjadi nilai plus bagi sekolah ini serta membedakannya dengan SLB lainnya terutama pada segi kurikulumnya.

Berdasarkan latar belakang tersebut, maka peneliti termotivasi untuk melakukan penelitian terkait dengan kurikulum yang diterapkan di Lentera Hati School khusunya pada program atau kelas pra sekolah. Penelitian ini berfokus pada pengembangan kurikulum serta implement asinya dalam pembelajaran dikelas ditinjau dari manajemen perubahan kurikulum.

\section{B. Pembahasan}

\section{Kajian Teori}

\section{a. Kurikulum}

Kurikulum berasal dari kata curir/ curere dalam bahasa Yunani yang diartikan sebagai jarak yang harus ditempuh oleh seorang pelari dalam dunia olahraga. Selanjutnya dalam dunia pendidikan, para pakar pendidikan mempunyai penafsiran yang berbeda tentang kurikulum namun tetap memiliki kesamaan yaitu bahwa kurikulum mempunyai hubungan yang erat dengan usaha pengembangan peserta didik sesuai dengan tujuan yang ingin dicapai (Sanjaya, 2015, p. 3)

Untuk menjelaskan sebuah teori kurikulum setidaknya memerlukan tiga konsep sebagai penjelasnya, kurikulum sebagai suatu substansi, kurikulum sebagai sistem, dan kurikulum sebagai bidang studi. Kurikulum sebagai suatu substansi yaitu, kurikulum dipandang sebagai suatu perangkat tujuan yang ingin dicapai, sehingga dapat pula dimaknai sebagai suatu dokumen yang berisikan rumusan tujuan, metode, media, bahan ajar beserta sumber hingga evaluasi.

Kurikulum sebagai suatu sistem memandang kurikulum sebagai bagian dari sistem persekolahan, sistem pendidikan, bahkan sistem masyarakat. Suatu sistem kurikulum mencakup pelaksana, prosedur kerja penyusunan kurikulum, pelaksanaan hingga evaluasi. Sedangkan kurikulum sebagai bidang studi yakni kurikulum sebagai bidang kajian para ahli. Dimana ilmu tentang kurikulum dan sistem kurikulum 
diharapkan dapat berkembang (Sudin, 2014, p. 3).

Pandangan tradisional memandang kurikulum sebagai sejumlah mata pelajaran yang perlu dipelajari oleh siswa pada jenjang tertentu. pengertian tersebut bertentangan dengan pandangan modern yang memaknai kurikulum sebagai sebuah pengalaman belajar siswa yang banyak kaitannya dengan berbagai kegiatan yang ada di sekolah mulai dari belajar di kelas, pramuka, olahraga, kegiatan ekstrakurikuler dan berbagai hal yang dilakukan siswa di sekolah. dengan demikian dapat dimaknai bahwa kurikulum tidak hanya sebatas mata pelajaran saja, namun seluruh kegiatan seperti interaksi sosial, proses pembelajaran, interaksi fisik dan lain sebagainya yang memberikan pengalaman belajar bagi siswa.

Melihat betapa luasnya kurikulum jika dimaknai sebagai pengalaman belajar yang kemudian akan menyulitkan dalam menyusun perencanaan maka Hilda Taba mencoba melihat kurikulum dari sisi yang berbeda. Hilda Taba mencoba melihat dari strukstur dan fungsinya, dimana pada umumnya kurikulum tersusun dari tujuan, isi, pola mengajar dan evaluasi. Pandangan ini senada dengan Ralph W.Tyler yang menjelaskan bahwa kurikulum sangat dekat dengan pengajaran sehingga dalam praktik pengembangan kurikulum sama hal nya dengan merencanakan pengajaran. Beberapa ahli mendefinisikan kurikulum sebagai berikut(Sarinah, 2015, p. 12):

1) Daniel Tanner dan Laurel Tanner. Kurikulum adalah pengalaman pembelajaran yang terarah dan terencana secara terstruktur dan tersusun melalui proses rekrontruksi pengetahuan dan pengalaman secara sistematis yang berada di bawah pengawasan lembaga pendidikan sehingga pelajar memiliki motivasi dan minat belajar.

2) Inlow. Kurikulum adalah usaha menyeluruh dirancang khusus oleh sekolah dalam membimbing murid memperoleh hasil dari pelajaran yang telah ditentukan.

3) Kerr, J. F. Kurikulum adalah sebuah pembelajaran yang dirancang dan dilaksanakan dengan individu dan berkelompok baik di luar maupun di dalam sekolah. 
4) George A. Beaucham. Kurikulum adalah sokumen tertulis yang mendukung isi mata pelajaran yagng diajarkan kepada peserta didik melalui berbagai mata pelajaran, pilihan disiplin ilmu, rumusan masalah dalam kehidupa sehari-hari.

5) Neagley dan Evans. Kurikulum adalah semua pengalaman yang telah dirancang oleh pihak sekolah untuk menolng para siswa dalam mencapai hasil belajar kepada kemampuan siswa.

6) Nomor 20 Tahun 2003 Tentang Sistem Pendidikan Nasional, Kurikulum adalah seperangkat rencana dan pengaturan mengenai tujuan, isi dan bahan pelajaran serta cara yang digunakan sebgai pedoman penyelenggaraan kegiatan pembelajaran untuk mencapai tujuan pendidikan tertentu (UU NO 20 Tahun 2003 tentang Sistem Pendidikan Nasional., n.d.).

Memperhatikan definisi tentang kurikulum, menunjukkan bahwa kurikulum menempati posisi yang central dalam pendidikan bahkan menjadi syarat mutlak. Jika dilihat lebih lanjut kurikulum memiliki tiga peran yang sangat penting diantaranya yakni peran konservatif, peranan kritis/ evaluative, dan peranan kreatif (Sudin, 2014, p. 8).

Ketiga peranan tersebut harus dapat berjalan dengan seimbang sehingga peranan kurikulum dapat berjalan dengan baik. Semua pihak bertanggung jawab akan terlaksananya peranan-peranan tersebut, sehingga pihak-pihak yang terkait seperti pemerinta, kepala sekolah, guru, orang tua, siswa, dan masyarakat harus memahami betul tujuan dan isi kurikulum.

Selain peran, tedapat pula fungsi kurikulum yang berbeda-beda tergantung pada siapa yang menggunakan. Kata fungsi berasal dari bahasa inggris function yang memiliki beberapa makna diantaranya yaitu kegunaan, jabatan, kedudukan, kegiatan, tugas dana lain sebagainya. Sehingga jika menilik fungsi dapat dilihat dari siapa pengguna objek tersebut. begitu juga kurikulum berbeda fungsinya tergantung pada siapa yang menggunakan kurikulum tersebut. Bagi pengawas dan kepala sekolah kurikulum berfungsi sebagai dasar melakukan controlling. Sedangkan bagi guru, kurikulum berfungsi 
sebagai pedoman untuk melakukan proses belajar mengajar. Dan bagi siswa kurikulum berfungsi sebagai pedoman untuk belajar. Khusus bagi sisiwa sebagai peserta didik, kurikulum mempunyai enam fungsi yakni fungsi penyesuaian, fungsi integrasi, fungsi diferensiasi, fungsi persiapan, fungsi, pemilihan, dan fungsi diagnostic (Shobirin, 2015, p. 19).

Agar dapat diaplikasikan sesuai dengan lembaga pelaksana, maka kurikulum harus mengalami pengebangan. Pengembangan kurikulum adalah proses perencanaan kurikulum agar menghasilkan rencana kurikulum yang luas dan spesifik yang harus disesuaikan dengan berbagai komponen situasi belajar-mengajar seperti penetapan jadwal, mata pelajaran, kegiatan, sumber dan alat ukur dan lain sebagainya. Beberapa karakteristik dalam pengembangan kurikulum adalah :

1) Rencana kurikulum harus dikembangkan dengan tujuan yang jelas.

2) Program kegiatan yang dilaksanakan di sekolah harus selaras dengan prosedur pengembangan kurikulum. Dengan kata lain dalam melaksankan kegiatan harus mengacu pada kurikulum yang ada.

3) Rencana kurikulum yang baik dapat menghasilkan proses belajar yang baik, karena berdasarkan kebutuhan dan minat siswa.

4) Rencana kurikulum harus mengen alkan dan mendorong diversitas di antara para siswa. Sehingga siswa dapat mengembangkan kemampuan dirinya sesuai dengan potensi yang dimiliki.

5) Rencana kurikulum harus menyiapkan semua aspek situasi belajar-mengajar seperti tujuan, konten, aktivitas, sumber, alat, pengukuran, penjadwalan, dan fasilitas yang menunjang.

6) Rencana kurikulum harus dikembangkan sesuai dengan karakteristik siswa pengguna. oleh karena itu pengembangan kurikulum harus memiliki gagasan yang jelas tentang tahapan perkembangan, gaya belajar, konsep awal, konsep diri, dan lainlain.

7) Rencana kurikulum harus berdifat fleksibel, sehingga dapat 
memberikan fleksibilitas untuk memungkinkan terjadi rencana guru-siswa. Termasuk di dalamnya memungkinkan masuknya ideide spontan dalam proses pembelajaran.

8) Rencana kurikulm hendaknya merefleksikan keseimbangan anata kognitif, afektif, dan psikomotorik (Hamalik, 2017, p. 11).

Melihat karakteristik dalam pengembangan kurikulum, dapat disimpulkan bahwa dalam melakukan pengembangan kurikulum harus berlandaskan pada beberapa prinsip baik prinsip umum maupun khusus. Prinsip umum dalam pengembangan kurikulum yakni prinsip berorientasi pada tujuan dan kompetensi, prinsip relevansi, prinsip efisiensi, prinsip keefektifan, prinsip fleksibilitas, prinsip integritas, prinsip kontinuitas, prinsip sinkronisasi, prinsip objektivitas, prinsip demokrasi. Adapun prinsip khusunya adalah prinsip -prinsip yang berkenaan dengan tujuan kurikulum, isi kurikulum, didaktik-metodik, kemudian prinsip yang berkenaan dengan media dan sumber belajar serta prinsip-prinsip evaluasi.

Implementasi kurikulum merupakan suatu proses penerapan konsep, ide dan kebijakan dalam suatu kegiatan yang diharapkan mampu memberikan efek positif kepada peningkatan kompetensi (kognitif, afektif, psikomotorik) siswa. menurut Mulyasa, implementasi kurikulum merupakan penerapan tatanan kurikulum dalam suatu praktik pembelajaran yang mengharapkan perubahanperubahan pada suatu kelompok, atau juga dapat dimaknai sebagai interaksi antara pendidik sebagai fasilitator dan peserta didik(Warni Tune Samar, 2016, p. 37). Menurut Miller dan Seller, implementasi kurikulum merupakan suatu penerapan konsep ide program atau tatanan kurikulum ke dalam praktik pembelajaran atau berbagai kreativitas baru sehingga terjadinya perubahan pada sekelompok orang yang diharapkan untuk berubah(Wahyudin, 2014, p. 94). Dengan demikian, imolementasi kurikulum adalah penerapan atau pelaksanaan program kurikulum yang telah dikembangkan dalam tahap sebelumnya, kemudian diujicobakan dengan pelaksanaan dan pengelolaan, dan disesuaikan dengan karakteristik dilapangan 
khususnya peserta $\operatorname{didik(Hamalik,~2017,~p.~238).~}$

Dalam imlpementasi kurikulum, terdapat dua tingkatan. Yang pertama berada di tingkat sekolah dan kepala sekolah yang menjadi penaggungjawabnya serta di tingkat kelas dimana guru menjadi penanggungjawabnya. Namun meskipun dibagi sedemikian rupa, namun kurikulum baik ditingkat sekolah maupun kelas harus selalu berjalan beriringan dan selaras. Jika kepala sekolah lebih sebagai pemimpin, Pembina, dan konseptor rencana tahunan, maka guru lebih menitik beratkan tugasnya pada tiga jenis kegiatan administrasi, yaitu tugas mengajar, bimbingan belajar, dan pembinaan ekstrakulikuler.

Hal lain yang perlu diperhatikan yakni pihak-pihak yang terkait dengan implementasi kurikulum. Stakeholder dalam implementai kurikulum mencakup, pakar ilmu pendidikan, ahli kurikulum, supervisor, sekolah, kepala sekolah, guru, siswa, orang tua dan masyarakat. Selain itu juga terdapat administrasi implementasi kurikulum yang berkenaan dengan seluruh perilaku yang berkaitan dengan semua tugas yang memungkinkan terlaksananya kurikulum. Tujuannya yaitu agar kurikulum dapat terlaksana dengan baik, dengan menyediakan fasilitas material, personal, dan kondisi-kondisi agar kurikulum dapat berjalan. Kegiatan administrasi kurikulum antara lain yaitu menyusun rencana kegiatan tahunan, menyusun rencana pelaksanaan program, menyusun jadwal pelaksanaan kegiatan, melaksanakan kegiatan proses belajar mengajar, mengatur pelaksanaan pengisian buku laporan pribadi, melaksanakan kegiatan-kegiatan ekstrakulikuler, melaksanakan evaluasi belajar tahap akhir, mengatur perlengkapan pendidikan, melaksanakan kegiatan bimbingan dan penyuluhan, merencanakan usaha-usaha peningkatan mutu guru (Wahyudin, 2014, p. 104).

Dalam implementasinya, kurikulum dipengaruhi oleh beberapa faktor diantaranya yaitu:

1) Karakteristik kurikulum, yang mencakup ruang lingkup bahan ajar, tujuan, fungsi, sifat dll.

2) Strategi implementasi, yaitu strategi yang digunakan untuk 
mendukung terdorongnya penggunaan kurikulum di lapangan seperti diskusi profesi, seminar, penataran dll

3) Karakteristik pengguna kurikulum, karakteristik ini berkaitang dengan pengetahuan pengguna kurikulum, ketrampilan, serta nilai dan sikap guru terhadap kurikulum di lapangan.

\section{b. Anak Berkebutuhan Khusus}

Kata abnormal dalam Kamus Besar Bahasa Indonesia, diartikan tidak sesuai dengan keadaan yang biasa, mempunyai kelainan dan tidak normal(Alwi, 2002, p. 2). Pada Undang-Undang R1 No. 2 Tahun 1989 tentang Sistem Pendidikan Nasional ditegaskan bahwa anak atau peserta didik yang memiliki kelainan fisik dan mental disebut dengan istilah anak luar biasa. Sedangkan dalam Undang-Undag N0. 20 Tahun 2003 tentang Sistem Pendidikan Nasional, anak yang memiliki kelainan fisik dan mental tersebut disebut dengan istilah anak berkebutuhan khusus.

Pedoman tentang anak berkebutuhan khusu atau yang selanjutnya disebut ABK menyatakan bahwa anak-anak dikatakan berkebutuhan khusus jika mereka memiliki kesulitan belajar sehingga menuntut dibuatnya ketentuan pendidikan khusus bagi mereka. Anak-anak disebut memilki kesulitan belajar jika mereka(Thompson, 2010, p. 3):

1) Memiliki kesulitan belajar yang jauh lebih besar dibandingkan kebanyakan anak seusia mereka

2) Memiliki ketidakmampuan yang menghambat atau menghalangi mereka dalam menggunakan fasilitas pendidikan yang umumnya disediakan untuk anak-anak seusia mereka di sekolah

3) Berada dalam usia wajib belajar dan memenuhi definisi (a) atau (b) diatas, atau memebuhi definisi tersebut jika ketentuan pendidikan khusu tidak dibuat untuk mereka .

Terdapat empat wilayah prinsip dari kebutuhan pendidikan khusu diantara yaitu komunikasi dan interaksi, kognisi dan pembelajaran, perkembangan tingkah laku, emosionla, dan social, sertaa kebutuhan sensori dan/atau fisik.

ABK atau yang serig disebut Anak berkebutuhan khusus adalah individu-individu yang mempunyai karakteristik yang berbeda dari 
individu yang lainnya yang di anggap normal. Secara lebih khusus anak berkebutuhan khusus menunjukkan karakteristik fisik, intelektual, dan emosional yang lebih rendah atau lebih tinggi dari anak normal sebayannya atau berada di luar standar normal yag berlakuu dimasyarakat. Sehigga megalami kesulitan dalam dalam meraih sukses baik dari segi sosial, personal, maupun aktivitas pendidikan.

Heward, ABK adalah anak dengan krakteristik khusus yanng berbeda dengan anak pada umumnya tanpa selalu menunjukkan pada ketidak mampuan mental, emosi, atau fisik. Menurut Suran dan Rizzo memberikan definisi bahwa Anak Berkebutuhan Khusus adalah anak yang secara signifikan bberbbeda dalam beberapa dimensi yang penting dari fungsi kemanusiaannya. Mereka yang secara fisik, psikologi, kognitif atau sosial terlambat dalam mencapai tujuan-tujuan atau kebutuhan dan potensinya secara maksimal, meliputi mereka yang tuli, buta, ganguan bicara, cacat tubuh, retardasi mental, gaguan emosional, juga anak-anak berbakat dengan intelegensi tinggi termasu kedalam ktegori anak berkebutuhan khusus karena memerlukan penaganan dari tenaga profesional terlatih.

Ada beberapa istilah yang digunakan untuk menunjukkan keadaan anak berkebutuhan khusus. Istilah anak berkebutuhan khusus merupakan istilah terbaru yang digunakan dan merupakan terjemahan dari children with special need yang telah digunakan secara luas di dunia internasioanl.Adapun pembagian anak berebutuahan khusus dibagi menjadi beberapa jenis yaitu tuna netra, tuna gahita, tuna laras, tuna wicara, tuna daksa, tuna ganda, tuna berbakat, tuna rungu.

\section{Metode Penelitian}

Penelitian ini merupakan penelitian lapangan (field research) dengan menggunaan pendekatan kualitatif deskriptif analitik. Sehingga dalam pengumpulan data terjadi interaksi antara peneliti dan sumber data (Sugiyono, 2014, p. 21). Karena untuk memahami fenomena secara menyeluruh tentunya harus memahami segenap konsep dan melakukan analisis secara holistik dan menjabarkannya secara deskriptif(Sugiyono, 2014, p. 290). Dalam penelitian deskriptif tidak ada perlakuan dan kendali yang dilakukan oleh peneliti. Penentuan subjek penelitian dilakukan 
dengan metode purposive sampling. Purposive sampling merupakan teknik pengambilan sampel sumber data dengan pertimbangan tertentu, misalnya orang dianggap paling paham dengan apa objek kajian penelitian atau orang yang dianggap sebaga penguasa sehingga peneliti dapat mudah menjelajahi objek/ situasi social yang diteliti(Sugiyono, 2012, p. 301). Subjek dari penelitian ini adalah pihak-pihak yang memahami dan menjadi pelaku atau pelaksana pada fokus kajian penelitian ini. Yaitu pihak yang melakukan perubahan dan pengembangan pada kurikulum yang ada di Lentera Hati School, serta pihak yang mengimplementasikan seperti pendidik dan terapis.

Teknik pengambilan data yang digunakan dalam penelitian kualitatif ini yakni observasi, wawancara, dokumentasi, dan Triangulasi. Dimana Triangulasi di sini dijadikan teknik pengambilan data sekaligus teknik keabsahan data. Adapun analisis data yang dilakukan dengan mengkasifikasikan data, reduksi data, penyajian data, dan conclusion (Sugiyono, 2012, p. 336).

\section{Hasil Penelitian}

\section{a. Proses Input Siswa}

Siswa yang belajar di Lentera Hati School mayoritas merupakan klien terapi di Yayasan Lentera Hati. Penerimaan siswa baru di Lentera Hati School tidak dilakukan seperti penerimaan siswa baru yang ada di lembaga pendidikan lainnya. Disamping merupakan kelanjutan dari sesi terapi, terdapat pula pendaftar dari luar. System penetapan kuota dan penerimaan siswa baru dalam setiap tahunnya juga tidak dapat di prediksi karena mengacu pada ketersediaan kursi, siswa masuk dan siswa yang lulus.

Dalam proses penerimaan siswa baru, Lentera Hati School melakukan beberapa tes yang dilakukan kepada siswa untuk mengetahui atau lebih tepatnya mendiagnosis jenis kebutuhan khusus apa yang mereka alami. Tes tersebut juga dilakukan untuk mengetahui mental age anak dan kemampuan didik anak tersebut. berdasarkan hasil tes yang dilakukan maka sekolah nantinya bisa menempatkan siswa di kelas yang tepat, selain itu juga dijadikan dasar sebagai guru dalam melakukan pembelajaran dan dasar treatmen bagi terapis dalam 
memberikan terapinya.

Sehingga, meskipun di ketika anak datang mendaftar sudah membawa hasil diagnose dari luar, tapi tetap akan di lakukan tes guna memastikan. Hasil tes tersebut selain di gunakan sebagai dasar penempatan juga sebagai dasar terapis untuk melakukan terapinya serta guru dalam mengembangkan kurikulum dan dasar pengembangan pembelajaran di kelas. Sehingga nantinya dengan dasar hasil tes tersebut lembaga dapat melaporkan kemajuan peserta didiknya sesuai dengan kekhususan yang mereka miliki.

\section{b. Struktur Kurikulum}

Kurikulum yang diterapkan di Lentera Hati School merupakan kurikulum adaptif yang di dasarkan pada kurikulum paud / TK regular yang kemudian disesuaikan dengan kebutuhan siswa yang ada di lembaga tersebut dengan menurunkan indicator pencapaiannya. Kurikulum mengacu pada permendikbud 146 dan 137 Tahun 2014 . Hal tersebut dilakukan karena mengunat belum adanya kurikulum baku dan khusus bagi pendidikan anak usia dini baik PAUD maupun TK Luar Biasa.

Pengembangan kurikulum yang dilakukan oleh Lentera Hati School selain dengan cara menurunkan indicator pencapaian juga dengan melakukan penyesuaian terhadap kekhususan yang miliki oleh masing-masing siswa mengingat bahwa kelas yang dimiliki oleh Lentera Hati School bersifat heterogen.

Adapun struktur kurikulum yang di laksanakan di Lentera Hati School yakni, (1) Kompetensi Inti dan Kompetensi Dasar (2) Standar Tingkat Pencapaian Perkembangan (STPP) dan Indikator Perkembangan. Penjabaran terkait dengan STTP dan Indikator Perkembangan yang ada di Lentera Hati School dapat di lihat pada tabel 1 . 


\begin{tabular}{|c|c|c|}
\hline No. & $\begin{array}{c}\text { Standat Tingkat } \\
\text { Pencapaian } \\
\text { Perkembangan (STTP) }\end{array}$ & Indikator Perkembangan \\
\hline \multirow[t]{3}{*}{1.} & Nilai Agama dan Moral & $\begin{array}{l}\text { a. Mengetahui Agama yang } \\
\text { dianutnya } \\
\text { b. Mengucapkan do'a sebelum dan } \\
\text { sesudah melaksanakan sesuatu } \\
\text { c. Mengucapkan salam dan } \\
\text { membalas salam } \\
\text { d. Mengenal perilaku baik/sopan } \\
\text { dan buruk } \\
\text { e. Membiasakan diri berperilaku } \\
\text { baik } \\
\text { f. Mulai meniru do'a pendek } \\
\text { sesuai dengan agamanya } \\
\text { g. Menghormati (toleransi) agama } \\
\text { orang lain }\end{array}$ \\
\hline & & $\begin{array}{l}\text { Motorik Kasar: } \\
\text { a. Berdiri dengan satu kaki } \\
\text { b. Melompat dari ketinggian } \pm 20 \\
\text { cm } \\
\text { c. Meniru gerakan senam } \\
\text { sederhana seperti pohon ditiup } \\
\text { angina, binatang, pesawat } \\
\text { terbang dll } \\
\text { d. Melempar dan menangkap } \\
\text { sesuatu secara terarah } \\
\text { e. Meniti di atas papan titian } \\
\text { f. Memanfaatkan alat permainan di } \\
\text { luar kelas } \\
\text { Terampil menggunakan tangan } \\
\text { kanan dan kiri }\end{array}$ \\
\hline & & $\begin{array}{l}\text { Motorik Halus: } \\
\text { a. Membuat garis vertical, } \\
\text { horizontal, lengkung kiri kanan, } \\
\text { miring kiri kanan, dan } \\
\text { lingkungan. } \\
\text { b. Mengontrol gerakan tangan yang } \\
\text { menggunakan otot halus } \\
\text { (menjumput, mencolek, } \\
\text { mengepal, meremas, memeras) } \\
\text { c. Mengekspresikan diri dengan } \\
\text { berkarya seni menggunakan } \\
\text { berbagai media } \\
\text { d. Meronce benda yang cukup } \\
\text { besar } \\
\text { e. Menggunting sesuai dengan pola }\end{array}$ \\
\hline
\end{tabular}




\begin{tabular}{|c|c|c|}
\hline No. & $\begin{array}{c}\text { Standat Tingkat } \\
\text { Pencapaian } \\
\text { Perkembangan (STTP) }\end{array}$ & Indikator Perkembangan \\
\hline & & $\begin{array}{l}\text { f. Menempel gambar dengan tepat } \\
\text { g. Menggunakan alat minum dan } \\
\text { alat makan dengan benar }\end{array}$ \\
\hline & & $\begin{array}{l}\text { Belajar dan Pemecahan Masalah } \\
\text { a. Mengenal benda berdasarkan } \\
\text { fungsinya } \\
\text { b. Mengetahui konsep banyak dan } \\
\text { sedikit } \\
\text { c. Mengerjakan tugas sampai } \\
\text { selesai } \\
\text { d. Menyebutkan nama makanan } \\
\text { dari rasanya (garam, gula, cabai) } \\
\text { e. Memahami posisi/ kedudukan } \\
\text { dalam keluarga/ lingkungan } \\
\text { social (missal sebagai anak } \\
\text { didik, teman, anak) }\end{array}$ \\
\hline & & $\begin{array}{l}\text { Berfikir Logis } \\
\text { a. Mengklasifikasikan benda } \\
\text { berdasarkan fungsi, bentuk, } \\
\text { warna, atau ukuran. } \\
\text { b. Mengenal gejala sebab akibat } \\
\text { yang terkait dengan dirinya } \\
\text { c. Menempatkan benda dalam } \\
\text { urutan ukuran (paling kecil- } \\
\text { paling besar) } \\
\text { d. Mulai mengikuti pola tepuk } \\
\text { tangan }\end{array}$ \\
\hline & & $\begin{array}{l}\text { Berfikir Simbolik } \\
\text { a. Membilang banyak benda 1-10 } \\
\text { b. Mengenal konsep bilangan } \\
\text { c. Mengenal lambing bilangan } \\
\text { d. Mencocokkan lambang bilangan } \\
\text { dengan nama bilangan } \\
\text { e. Mengenal lambang huruf } \\
\text { f. Mengenal berbagai macam } \\
\text { lambang huru vocal dan } \\
\text { konsonan }\end{array}$ \\
\hline 4. & Bahasa & $\begin{array}{l}\text { Memahami Bahasa } \\
\text { a. Menyimak perkataan orang lain } \\
\text { b. Mengerti dua perintah yang } \\
\text { diberikan secara bersamaan } \\
\text { c. Mengenal pembendaharaa kata } \\
\text { mengenai kata sifat (nakal, pelit, } \\
\text { baik hati, berani, jelek dsb) }\end{array}$ \\
\hline
\end{tabular}




\begin{tabular}{|c|c|c|}
\hline No. & $\begin{array}{c}\text { Standat Tingkat } \\
\text { Pencapaian } \\
\text { Perkembangan (STTP) }\end{array}$ & Indikator Perkembangan \\
\hline & & $\begin{array}{l}\text { d. Memahami aturan dalam suatu } \\
\text { permainan }\end{array}$ \\
\hline & & $\begin{array}{l}\text { Mengungkapkan Bahasa } \\
\text { a. Mengulang kalimat sederhana } \\
\text { b. Bertanya dengan kalimat } \\
\text { sederhana } \\
\text { c. Menjawab pertanyaan sesuai } \\
\text { pertanyaan } \\
\text { d. Menyatakan alas an terhadap } \\
\text { sesuatu yang diinginkan/ } \\
\text { ketidaksetujuan } \\
\text { e. Menyatakan keinginan dengan } \\
\text { kalimat sederhana }\end{array}$ \\
\hline & & $\begin{array}{l}\text { Keaksaraan } \\
\text { a. Mengenal simbol-simbol } \\
\text { b. Menyebutkan simbol-simbol } \\
\text { huruf yang dikenal } \\
\text { c. Mengenal suara-suara hewan / } \\
\text { benda yang ada di sekitarnya } \\
\text { d. Mengenal suara huruf awal } \\
\text { namanya dan nama benda-benda } \\
\text { disekitarnya } \\
\text { e. Membuat coretan bermakna } \\
\text { f. Meniru (menuliskan dan } \\
\text { mengucapkan) huruf A-Z } \\
\text { g. Memahami hubungan antara } \\
\text { bunyi dan bentuk huruf } \\
\text { h. Membaca namanya sendiri }\end{array}$ \\
\hline & & $\begin{array}{l}\text { Kesadaran Diri } \\
\text { a. Menunjukkan sikap mandiri } \\
\text { dalam memilih kegiatan } \\
\text { b. Meniru apa yang dilakukan } \\
\text { orang lain } \\
\text { c. Mengendalikan perasaan } \\
\text { d. Bereaksi terhadap hal-hal yang } \\
\text { tidak benar (marah jika } \\
\text { diganggu) } \\
\text { e. Menunjukkan rasa percaya diri } \\
\text { f. Memahami peraturan dan } \\
\text { disiplin } \\
\text { g. Memiliki sifat gigih (tidak } \\
\text { mudah menyerah) } \\
\text { h. Bangga dengan hasil karya } \\
\text { i. Mendiri }\end{array}$ \\
\hline
\end{tabular}




\begin{tabular}{|c|c|c|}
\hline No. & $\begin{array}{c}\text { Standat Tingkat } \\
\text { Pencapaian } \\
\text { Perkembangan (STTP) }\end{array}$ & Indikator Perkembangan \\
\hline & & $\begin{array}{l}\text { hatian kepada orang yang belum } \\
\text { dikenal (menumbuhkan } \\
\text { kepercayaan kepada orang } \\
\text { dewasa yang tepat }\end{array}$ \\
\hline & & $\begin{array}{l}\text { Rasa Tanggung Jawab Untuk Diri } \\
\text { Sendiri Dan Orang Lain } \\
\text { a. Melakukan buang air kecil } \\
\text { (toilet training) } \\
\text { b. Bersabar menunggu giliran } \\
\text { c. Menunjukkan ekspresi menyesal } \\
\text { ketika melakukan kesalahan } \\
\text { d. Mentaati peraturan kelas } \\
\text { e. Mau berbagi, menolong, dan } \\
\text { membantu teman }\end{array}$ \\
\hline & & $\begin{array}{l}\text { Perilaku Prososial } \\
\text { a. Membangun kerjasama } \\
\text { (bermain dengan teman) } \\
\text { b. Mengetahui perasaan teman } \\
\text { c. Menghargai keunggulan teman/ } \\
\text { orang lain } \\
\text { d. Mengekspresikan emosi sesuai } \\
\text { dengan kondisi yang ada } \\
\text { e. Mengenal tata karma dan sopan } \\
\text { santun sesuai dengan nilai social } \\
\text { dan budaya setempat }\end{array}$ \\
\hline & & $\begin{array}{l}\text { Anak Mampu Menikmati Alunan } \\
\text { Lagu dan Suara } \\
\text { a. Senang mendengarkan berbagai } \\
\text { macam music dan lagu } \\
\text { kesukaannya } \\
\text { b. Bersenandung/ bernyanyi sambil } \\
\text { mengerjakan sesuatu } \\
\text { c. Memainkan alat } \\
\text { music/instrument/benda } \\
\text { bersamateman }\end{array}$ \\
\hline & & $\begin{array}{l}\text { Tertarik Dengan Kegiatan Seni } \\
\text { a. Bernyanyi sendiri } \\
\text { b. Memilih jenis lagu yang disukai } \\
\text { c. Menyanyikan lagu dengan sikap } \\
\text { yang benar } \\
\text { d. Mengekpresikan gerakan dengan } \\
\text { irama yang bervariasi } \\
\text { e. Menggambar objek di sekitarnya } \\
\text { f. Mengkombinasikan warna ketika } \\
\text { menggambar dan mewarnai } \\
\text { g. Membentuk berdaarkan objek }\end{array}$ \\
\hline
\end{tabular}




\begin{tabular}{|c|c|c|}
\hline No. & $\begin{array}{c}\text { Standat Tingkat } \\
\text { Pencapaian } \\
\text { Perkembangan (STTP) }\end{array}$ & Indikator Perkembangan \\
\hline & & $\begin{array}{l}\text { yang dilihat missal plastisin, } \\
\text { kertas, pasir, tanah liat, balok }\end{array}$ \\
\hline
\end{tabular}

Standar Tingkat Pencapaian dirumuskan dengan memperhatian Standar Tingkat Pencapaian yang ada pada panduan Kurikulum PAUD, yang kemudian disesuaikan dengan kebutuhan dan keadan anak di lapangan. Untuk Kompetensi Dasar, dalam hal ini Lentera Hati School melakukan modifikasi yakni disesuaikan dengan kemampuan didik para peserta didik. Hal tersebut juga disesuaikan dengan standar indicator pencapaian.

Rencana Pelaksanaan Pembelajaran Mingguan (RPPM) dan Rencana Pelaksanaan Harian atau Rencana Pelaksanaan Pembelajaran Harian (RPPH) yang dikembangkan oleh Lentera Hati School juga mengalami modifikasi baik secara susunan maupun komponen di dalamnya. Beberapa komponen yang ada dalam RPPH diantaranya yaitu.

1) Identitas RPPH (semester/ bulan/ minggu, Kelompok, Tema/Sub Tema, Hari Tanggal, Waktu

2) Materi (Pembiasaan dan Kegiatan)

3) Alat dan Bahan

4) Pelaksanaan Kegiatan (Kegiatan awal, Inti, dan akhir/ penutup)

5) Keterangan Penilaian ( Belum berkembang, mulai berkembang, berkembang sesuai harapan, berkembang sangat baik yang dilambang dengan simbol)

6) Hasil Penilaian (Termasuk Nama-Nama siswa)

7) Penangung Jawab (Kepala Sekolah dan PJ Pree School)

Pelaksanaan Pembelajaran dilaksanakan sesuai dengan kalender akademik. Untuk kalender akademik Lentera Hati mengikuti kalender akademik KB-TK PAUD Jawa Tengah.

\section{c. Proses Pelaksanaan Pembelajaran}

Berdasarkan Standar Operasioanal (SOP) yang ada di Lentera Hati School, kegiatan di sekolah dimulai pada pukul 07.00 hingga 
pukul 12.00 dan berlaku dari Senin hingga Jum'at. SOP Pembelajaran Pre School tertuang dalam tabel 2.

Tabel 2. SOP Pembelajaran Pre School

\begin{tabular}{|c|l|l|}
\hline NO & \multicolumn{1}{|c|}{ JAM } & \multicolumn{1}{c|}{ KEGIATAN } \\
\hline 1. & 07.00 & Penataan lingkungan sekolah (kebersihan) \\
\hline 2. & $07.00-08.00$ & Proses penyambutan anak \\
\hline 3. & $08.00-08.30$ & $\begin{array}{l}\text { Kegiatan keagamaan } \\
\text { Toilet training }\end{array}$ \\
\hline 4. & $08.30-09.00$ & Pembukaan (Kegiatan Awal) \\
\hline 5. & $09.00-09.45$ & Kegiatan Inti \\
\hline 6. & $09.45-10.00$ & Kegiatan akhir (Penutup) \\
\hline 7. & $\begin{array}{l}10.00-10.15 \\
10.15-10.30\end{array}$ & $\begin{array}{l}\text { Toilet Training } \\
\text { Snack }\end{array}$ \\
\hline 8. & $10.30-11.00$ & $\begin{array}{l}\text { Istirahat / terapi bagi yang memiliki jadwal } \\
\text { terapi }\end{array}$ \\
\hline 9. & 11.00 & Makan siang bagi yang membawa bekal \\
\hline 10. & $11.00-12.00$ & $\begin{array}{l}\text { Saat penjemputan (Jum'at } \\
\text { penjemputan maksimal 11.00) }\end{array}$ \\
\hline
\end{tabular}

Dari tabel 2 proses pembelajan dibagi menjadi 4 bagian yaitu kegiatan keagamaan, kegiatan awal, kegiatan inti, dan kegiatan akhir. Kegiatan keagamaan berupa mengaji bagi siswa muslim dan legiatan lain bagi siswa non muslim. Mengaji ini menjadi salah satu program unggulan dari Lentera Hati School. Kegiatan toilet traning juga menjadi kegiatan rutin bagi anak-anak. Tujuannya adalah agar anak mampu secara mandiri untuk melakukan buang air kecil maupun besar. Setiap anak yang akan ke kamar mandi akan didampingi oleh satu guru shadow yang akan membantu mengarahkan seperti meminta untuk melepasakan dan mengenakan celana secara mandiri.

Kedua yakni kegiatan pembukaan yang terdiri dari do'a sebelum kegiatan, fisik motoric dan bernyanyi atau tepuk-tepuk. Kegiatan berdoa dilakukan dengan cara duduk melingkar dan dipandu oleh guru kelas dan didampingi oleh para guru shadow. Doa yang digunakan yaitu doa berbahasa arab dan doa yang menggunakan bahasa Indonesia. Hal ini dilakukan guna lebih memahamkan anak serta menghormati anak yang beragama non muslim. Dilanjutkan dengan kegiatan bernyanyi dengan gerakan seperti tepuk-tepuk atau gerakan tangan sederhana. Hal ini bertujuan untuk merangsang anak agar mampu mengikuti instruksi, belajar konsentrasi dan saraf-saraf 
motoriknya. selain itu juga ada kegiatan fisik motorik, contoh kegiatan yang dilakukan yakni meniti diatas titian yang medianya sudah disediakan di dalan kelas. Kegiatan ini bertujuan untuk merangsang motoric anak, konsentrasi dan keberanian anak

Ketika peneliti melakukan observasi, peneliti melihat kegiatan meniti ini, sesuai dengan apa yang disampaikan oleh bu Said bahwa anak yang berani meniti dan melompat dari titian terlihat nampak lebih sigap dalam melakukan dan menerima pelajaran. Sedangkan anak yang masih perlu diberikan dorongan baik secara verbal dan perlakuan terlihat kurang siap dalam mengikuti pembelajaran.

Ketiga, kegiatan inti. Kegiatan pembelajaran ini mencakup 6 aspek perkembangan yakni Nilai Agama dan Moral, Fisik Motorik, Kognitif, Bahasa, Sosial Emosi, Seni dan Kreatifitas. Dalam setiap kegiatan ini disesuaiakan dengan karakteristik dan kondisi masingmasing anak dengan mengutamakan pengembangan komunikasi, ketrampilan bantu diri (life skills) ketrampilan berperilaku, mengajarkan hal lain seperti calistung sesuai dengan kematangan intelegensi anak dan yang terakhi yaitu melatih konsentrasi.

Pembelajaran dimulai dengan doa, kemudian dilanjutkan dengan meniti dan melompat, bernyanyi sambil membuka dan menutup tangan, kegiatan pembelajaran, makan snack dan doa penutup. Pembelajaran yang dilakukan yakni berupa menebalkan huruf dengan media buku dan pensil. Diteruskan dengan mencocokkan warna dengan media peraut pensil yang berwana-warni. Selanjutnya yakni menggambar dengan menggunakan tangan dengan media kertas dan pewarna makanan. Pada saat ini terdapat dua anak yang melakukan pembelajaran yang berbeda. Satu anak autis yang melakukan hitung chain dan dimasukkan ke dalam wadah serta satu anak hiperaktif yang belajar memasukkan kelereng ke dalam botol.

Berbagai macam kegitan inti yang dilakuka di Lentera Hati School dapat di lihat lewat contoh Rencana Pelaksanaan Pembelajaran Mingguan (RPPM) dengan Sub Tema Diriku/ Identitas pada tabel 3. 


\begin{tabular}{|c|c|c|c|}
\hline NO & $\begin{array}{c}\text { ASPEK } \\
\text { PERKEMBA } \\
\text { NGAN }\end{array}$ & INDIKATOR & $\begin{array}{l}\text { RENCANA } \\
\text { KEGIATAN }\end{array}$ \\
\hline 1. & $\begin{array}{l}\text { Nilai Agama } \\
\text { dan Moral }\end{array}$ & $\begin{array}{l}\text { a. Do'a sebelum dan } \\
\text { sesudah melakukan } \\
\text { kegiatan } \\
\text { b. Mengucapkan dan } \\
\text { menjawab salam }\end{array}$ & $\begin{array}{l}\text { a. Doa sebelum dan } \\
\text { sesudah belajar, } \\
\text { makan, dan } \\
\text { minum } \\
\text { b. Mengucapkan } \\
\text { dan menjawab } \\
\text { salam }\end{array}$ \\
\hline 2. & Fisik Motorik & $\begin{array}{l}\text { Motorik Kasar } \\
\text { a. Melempar tangkap } \\
\text { sesuatu secara } \\
\text { terarah } \\
\text { b. Berlatih } \\
\text { keseimbangan } \\
\text { c. Terampil } \\
\text { menggunakan tangan } \\
\text { Motorik Halus gerakan } \\
\text { a. Mengontrol gang } \\
\text { tangan otot } \\
\text { menggunakan (menjumput, } \\
\text { halus mel, } \\
\text { mencolek, mengepel, } \\
\text { meremas. Menjepit, } \\
\text { menyobek) } \\
\text { b. Meronce }\end{array}$ & $\begin{array}{l}\text { a. Lempar tangkap } \\
\text { bola } \\
\text { b. Berdiri satu kali } \\
\text { c. Bermain tepuk } \\
\\
\text { a. Meremas kertas } \\
\text { b. Bermain buka } \\
\text { tutup } \\
\text { c. Berjalan maju } \\
\text { mundur menjepit } \\
\text { angka } \\
\text { a. Meronce rantai } \\
\text { b. Meronce huruf } \\
\text { vocal } \\
\text { c. Meronce kartu } \\
\text { angka }\end{array}$ \\
\hline 3. & Kognitif & $\begin{array}{l}\text { Pemecahan Masalah } \\
\text { a. Mengerjakan tugas } \\
\text { sampai selesai } \\
\text { b. Memahami posisi } \\
\text { dan kedudukan } \\
\text { dalam keluarga } \\
\text { lingkungan social } \\
\text { Berfikir Logis } \\
\text { a. Mengklasifikasikan } \\
\text { benda berdasarkan } \\
\text { fungsi, bentuk, } \\
\text { warna, ukuran. } \\
\text { b. Mengikuti pola } \\
\text { tepuk tangan }\end{array}$ & $\begin{array}{l}\text { a. Menyelesaikan } \\
\text { tugas } \\
\text { b. Menyebutkan } \\
\text { nama diri, orang } \\
\text { tua, alamat } \\
\\
\text { a. Mengurutkan } \\
\text { warna } \\
\text { b. Menyusun balok } \\
\text { menara } \\
\text { c. Maching warna } \\
\text { d. tepuk }\end{array}$ \\
\hline
\end{tabular}




\begin{tabular}{|c|c|c|c|}
\hline NO & $\begin{array}{c}\text { ASPEK } \\
\text { PERKEMBA } \\
\text { NGAN }\end{array}$ & INDIKATOR & $\begin{array}{l}\text { RENCANA } \\
\text { KEGIATAN }\end{array}$ \\
\hline & & $\begin{array}{l}\text { Berfikis Simbolik } \\
\text { a. Mengenal lambang } \\
\text { bilangan } \\
\text { b. Mengenal lambang } \\
\text { huruf }\end{array}$ & $\begin{array}{l}\text { a. Menebali dan } \\
\text { meniru angka 1- } \\
10 \\
\text { b. Maching warna } \\
\text { c. Meniru dan } \\
\text { menebali nama } \\
\text { diri }\end{array}$ \\
\hline 4. & $\begin{array}{l}\text { Bahasa } \\
\text { Sosial Emosi } \\
\text { Seni }\end{array}$ & $\begin{array}{l}\text { a. Memahami bahasa, } \\
\text { menyimak perkataan } \\
\text { orang lain } \\
\text { b. Menjawab } \\
\text { pertanyaan sesuai } \\
\text { dengan pertanyaan } \\
\text { c. Mengulang kalimat } \\
\text { sederhana } \\
\text { d. Toilet training } \\
\text { e. Mewarnai }\end{array}$ & $\begin{array}{l}\text { a. Mendengarkan } \\
\text { b. Tanya jawab } \\
\text { tentang identitas } \\
\text { c. Mengulang kata } \\
\text { atau kalimat } \\
\text { d. Toilet training } \\
\text { e. Mewarnai }\end{array}$ \\
\hline
\end{tabular}

Keempat, kegiatan akhir atau penutup. Kegiatan ini dilakukan dengan para siswa dan guru duduk melingkar kemudian melakukan repetisi terhadap materi yang telah dipelajari pada hari tersebut kemudian melakukan doa penutup yang kemudian dilanjutkan dengan mengingatkan agenda apa yang harus siswa lakukan seperti makan, mandi, tidur dan lain sebagainya. Setelah proses pembelajaran selesai siswa akan beristirahat sambil memakan snack yang dibawa ataupun disiapkan.

Kegiatan selanjutnya yaitu jadwal terapi bagi siswa yang mempunyai jadwal. Terapi ini tidak dilakukan oleh guru kelas, namun dilakukan oleh SDM khusus atau terapis yang memang berkompeten melakukan terapi. Kegiatan ini sangat menunjang proses pengembangan diri siswa. Selain terapi siswa juga mendapatkan daftar makanan yang perlu dihindari. Diet makanan ini juga bertujuan untuk meyesuaikan kebutuhan siswa dan membantu proses pembelajaran.

Setelah sesi terapi selesai maka anak boleh pulang. Pada moment penjemputan inilah banyak dari wali murid sering berkonsultasi dengan guru maupun kepala sekolah terkait dengan perkembangan anak baik yang ada di sekolah maupun yang anak lakukan di rumah. 
Meskipun pada setiap bulannya sekolah mengadakan acara parenting, namun kegiatan bertemu kepala sekolah maupun guru secara personal masih sering dilakukan.

\section{d. Media dan Sumber Belajar}

Media yang digunakan dalam proses pembelajaran di kelas Lentera Hati School sangatlah beragam dan di sesuaikan dengan kebutuhan dan kemampuan anak dalam belajar. Media yang digunakan merupakan media yang sederhana dan tidak membahayakan bagi siswa. Beberapa media pembelajaran yang digunakan sesuai dengan tujuan pembelajarannya baik audio maupun visual, diantaranya yaitu:

1) Media belajar menulis: Buku paket, buku ajar, pensil

2) Media belajar warna: warna makanan, rautan berwarna, bola berwarna

3) Media belajar motorik: radio/tape/kaset/ titian

4) Media belajar motorik halus dan kasar: pewarna makanan, mainan bongkar pasang, botol, titian besi

Penggunaan media dalam proses pembelajaran ABK menjadi sebuah kebutuhan yang sangat central, karena hampir seluruh pembelajaran yang dilakukan merupakan pembelajaran praktik bukan teori. Sehingga untuk memudahkan dalam melakukan pembelajaran sangat membutuhkan media sebagai pengantar pembelajaran. Sedangkan sumber belajar yang digunakan masih menjadikan guru sebagai sumber belajar utama. Meskipun di sediakan buku ajar dan buku latihan namun guru tetap menjadi sumber belajar yang utama.

\section{e. System Penilaian Hasil Belajar}

Sistem penilaian dilakukan dengan melaksanakan pengayaan terhadap indicator-indikator yang belum tercapai. Kegiatan tersebut dilaksankan setelah guru melakukan pengulanganterhadap materi yang telah diberikan. Penilaian hasil belajar dilakukan pada tengah semester dan juga akhir semester untuk mengetahui sejauh mana perkembangan dan hasil belajar siswa. Selain penilaian pada tengah dan akhir semester, penilaian harian juga dilakukan guna menilai proses perkembangan siswa. Penilaian ini dilakukan dengan cara guru melakukan observasi dan proses kegiatan pembelajaran dan hasil 
portofolio hasil karya anak

Dalam pelaporan hasil belajar siswa, aspek yang dilaporkan tidak hanya terkait dengan penilaian di kelas saja namun juga hasil perkembangan terapi. Penyelarasan antara penilaian kelas dan hasil laporan terapi bertujuan agar lembaga dan wali dapat mengetahui sejauh mana perkembangan yang ditunjukkan oleh siswa. Apakah menunjukkan kemajuan, stagnan, atau malah kemunduran. Dengan demikian lembaga dan wali dapat melakukan langkah selanjutnya baik dalam terapi maupun treatmen pembelajaran dalam kelas.

Laporan hasil perkembangan anak disajikan dalam buku laporan perkembangan anak yang diberikan dua kali dalam satu tahun yaitu pada semester pertama dan kedua. Buku tersebut mencakup beberapa komponen diantaranya yakni petunjuk penilaian, biodata anak, aspek perkembangan dan indikator perkembangan, deskripsi perkembangan anak, catatan keadaan jasmani da kesehatan anak, dan saran orang tua. Petunjuk penilaian perkembangan anak dalam laporan dibagi menjadi beberapa kriteria sebagai berikut:

BB

MB

BSB

: Belum Berkembang

Anak masih selalu dibimbing dan dicontohkan

: Mulai Berkembang

Anak masih harus diingatkan dan dibantu

: Berkembang Sesuai Harapan

Anak sudah dapat melakukan secara mandiri tanpa harus diingatkan atau dicontohkan dan dibantu oleh guru.

: Berkembang Sangat Baik

Anak sudah dapat melakukan secara mandiri dan membantu teman yang belum dicapai kemampuan sesuai dengan indikator yang dikembangkan.

\section{f. Implementasi Kurikulum Anak Berkebutuhan Khusus di Lentera Hati School.}

Pengembangan kurikulum ABK di Lentera Hati belum dapat dilakukan secara maksimal meskipun sebagian besar sudah mengacu pada prinsip-prinsip pengembangan kurikulum khususnya yang berkaitan dengan kebutuhan masing-masing siswa. Namun, dikarenakan kurangnya sumber daya manusia dalam hal guru kelas 
atau guru pokok menjadikan guru lebih mengedepankan atau mengutamakan proses pelaksanaan pembelajaran di kelas. Sehingga dalam hal perecanaan kurikulum belum dapat dilakukan dengan maksimal. Melihat bahwa adminitrasi atau pendokumentasian pelaksanaan pendidikan masih belum terdokumentasi dengan baik.

Tidak tersedianya kurikulum luar biasa bagi jenjang Pendidikan Anak Usia Dini, menjadikan Lentera Hati School harus menggunakan kurikulum 2013 PAUD. Karena keadaan tersebut, kurikulum yang dikembangkan dan diterapkan di Lentera Hati School dengan konsep pengembangan kurikulum adaptif, karena disesuaikan dengan kebutuhan dan keadaan anak-anak di lapangan. Penyesuaian dilakukan pada penurunan indicator pencapaain dan sub materi yang diberikan. Hal ini dilakukan agar pembelajaran sesuai dengan kemampuan yang dimiliki oleh siswa. Meski tidak dituliskan secara langsung pada Rencana Pelaksanaan Pembelajaran Mingguan (RPPM) dan Rencana Pelaksanaan Pembelajaran Harian (RPPH) atau tertulis dalam Rencana Pelaksanaan Pembelajaran Individu, namun pengembangan kurikulum tidak hanya dilakukan pada tingkat kelas saja tetapi juga pada tingkat individu. Hal tersebut dilakukan guna mengakomodasi kelas di Lentera Hari School yang bersifat heterogen.

Tidak tersedianya kurikulum baku dan pengembangan kurikulum yang dilakukan masih terkesan try and error, implementasi kurikulum belum dapat dievaluasi dengan pasti. Apakah pembelajaran yang dilakukan di Lentera Hati School sudah dapat dikategorikan berjalan dengan baik atau tidak karena belum mempunyai standar yang jelas. Untuk kegiatan pembelajaran yang telah dilakukan berdasarkan pengamatan peneliti sudah sesuai dengan apa yang telah direncanakan baik dalam RPPM ataupun RPPH. Namun peran guru kelas sangat dominan dibandingkan dengan guru shadow, sehingga ketika guru kelas sedang tidak bisa berada di kelas secara maksimal maka pembelajaran di kelas tidak bisa berjalan dengan baik. Khususnya dalam memberikan pembelajaran pada anak yang mendapat materi khusus saat pembelajaran. 
Pemberian materi pembelajaran yang berbeda meski dalam satu kelas, juga menjadi suatu hal yang menjadikan implementasi kurikulum pembelajaran menjadi terhambat. Baik pada tahap proses pembelajarn maupun proses penilaian. Sehingga dapat menjadi kemungkinan penilaian juga tidak dapat dilakukan seobjektif mungkin. Media pembelajaran yang digunakan dalam proses pembelajaran masih sangat sederhana. Meskipun demikian tujuan pembelajaran dapat terakomodir dengan media yang digunakan. Desain kelas yang polos sengaja dilakukan agar lebih menambah daya konsentrasi siswa. Meski dengan mengenyampingkan nilai-nilai estetika. Sedangkan sumber belajar yang di gunakan masih mengandalkan materi yang disiapkan oleh guru, dan buku kegiatan siswa sudah digunakan meskipun masih minim sekali.

Faktor internal lembaga yang menjadi penghambat dalam implementasi kurikulum yaitu dari unsur SDM nya. Tidak tersedianya aturan yang jelas atau system pengelolaan SDM yang belum terkelola dengan baik menyebabkan sering terjadinya pergantian guru. Jelas keadaan ini sangat mempengaruhi proses pembelajaran, baik dari perencanaan hingga pada tahap evaluasi. Meskipun rasio antara guru dan siswa masih termasuk dalam kategori ideal, namun jika guru selalu keluar masuk akan memberikan dampak yang negatif. Salah satunya yaitu tidak terdokumentasikannya administrasi lembaga dengan baik serta proses pembelajaran yang selalu membutuhkan adaptasi.

Keadaan SDM di Lentera Hati School yang sedemikian rupa juga memberikan dampak positif di satu sisi. System seleksi alam yang diterapkan oleh kepala sekolah menyisakan guru-guru yang memang mempunyai dedikasi yang tinggi pada profesinya. Hal ini berdampak pada koordinasi dan kerjasama yang baik antara SDM. Baik itu guru kelas dengan guru shadow, ataupun antara guru dengan para terapis. Rasa tanggung jawab yang tinggi dan panggilan hati menjadikan mereka totalitas dalam bekerja.

Faktor eksternal yang muncul dari luar lembaga dan menjadi penghambat yaitu belum adanya kurikulum bagi ABK ditingkat 
PAUD. Keadaan tersebut menjadikan kurikulum yang digunakan masih pada tahap pengembangan yang belum matang dan belum terukur keefektifannya dalam mencapai tujuan. Sehingga secara tidak langsung proses pembelajarannya pun belum memiliki standar yang jelas. Ditambah lagi keadaan kelas yang bersifat heterogen menjadi salah satu kendala yang serius. Meskipun dalam eksekusi perencanaan pembelajarannya sangat menjunjung prinsip fleksibilitas namun dibandingkan dengan kelas yang memang homogen hasilnya akan jauh lebih baik. Hal ini dikarenakan dalam kelas yng sifatnya heterogen fokus pembelajarnnya jelas akan terpecah.

Keluarga yang kooperatif dan peduli pada perkembangan anaknya menjadi faktor ekternal menjadi faktor yang mendukung proses pembelajaran. Kepatuhan orang tua terhadap saran-saran yang diberikan oleh lembaga mejadi penunjang keberhasilan pendidikan anak-anak mereka. Hubungan yang harnonis dan pelayanan yang memuaskan menjadikan para wali selalu nyaman untuk melakukan konsultasi. Terlayaninya para stakeholder tersebit juga didukung dengan jumlah siswa yang diterima untuk bersekolah di Lentera Hati Shool tidaklah banyak. Lembaga ini lebih mengedepankan kualitas daripada kuantitas. Sehingga memiliki sejumlah siswa yang tidak banyak bukanlah suatu masalah daripada siswa banyak namun tidak terlayani dengan baik. Hal tersebut dilakukan berdasarkan pertimbangan jumlah SDM serta sarana dan prasarana yang dimilki.

\section{Simpulan}

Lentera Hati School yang didirikan bermula dari kegiatan terapi menjadi dasar yang kuat, khas dan membedakan dari sekolah-sekolah yang lain. Dasar terapi ini juga yang menjadikan Lentera Hati School meski dalam pengembangan kurikulumnya belum maksimal namun dapat memberikan pelayanan yang cukup optimal bagi para peserta didiknya. Implementasi kurikulum yang ada di Lentera Hati dapat dikatakan sudah berjalan dengan baik pada tataran proses pembelajarannya. Namun pada sisi perencanaan dan evaluasi masih membutuhkan perbaikan. Proses pembelajaran masih diutamakan atau diprioritaskan dari perencanaannya. Sehingga hasil dari 
implementasi yang dilakukan belum dapat terukur dengan jelas dari sisi keefektifan maupun efisiensinya. Meskipun kelas bersifat heterogen, yakni berisikan kekhususan yang beragam dari para siswa. Namun proses pembelajaran yang dilakukan sangat menjunjung tinggi kekhususan antar individu. Sehingga komposisi dan kebutuhan pembelajaran setiap individu dapat teratasi dengan baik. Evaluasi pembelajaran tidak berdiri sendiri dari unsur pendidik saja namun dari terapi yang dilakukan oleh terapis. Pembandingan kedua hasil tersebut menjadi dasar pengembangan bagi pembelajaran dan treatment bagi siswa. Sehingga beberapa hal yang dapat menggangu berjalannya proses pembelajaran dapat diantisipasi lebih awal. Faktor penghambat utama dalam implementasi kurikulum di Lentera Hati School yaitu belum adanya panduan baku kurikulum ABK PAUD. Sedangkan pengembangan kurikulum belum dilakukan secara maksimal. 


\section{Daftar Pustaka}

Alwi, H. (2002). Kamus Besar Bahasa Indonesia. Jakarta: Balai Pustaka.

Hamalik, O. (2017). Dasar-Dasar Pengembangan Kurikulum. Bandung: Remaja Rosdakarya.

Haryono, S. A. D. (2015). Evaluasi Pendidikan Inklusif Bagi Anak Berkebutuhan Khusus (ABK) di Provinsi Jawa Tengah. Jurnal Penelitian Pendidikan.

Sanjaya, W. (2015). Kurikulum dan Pembelajaran. Jakarta: Prenada Media.

Sarinah. (2015). Pengantar Kurikulum. Yogyakarta: Deepublish.

Shobirin, M. (2015). Konsep dan Implementasi Kurikulum 2013 di Sekolah Dasar.

Sudin, A. (2014). Kurikulum dan Pembelajaran. Bandung: UPI Press.

Sugiyono. (2012). Metode Penelitian Kombinasi (Mixied Methods). Bandung: Alfabeta.

Sugiyono. (2014). Metode Penelitian Pendidikan Kualitatif, Kuantitatif, dan RnD. Bandung: Alfabeta.

Thompson, J. (2010). Memahami Anak Berkebutuhan Khusus. Surabaya: Erlangga.

UU NO 20 Tahun 2003 tentang Sistem Pendidikan Nasional. (n.d.).

Wahyudin, D. (2014). Manajemen Kurikulum. Bandung: Remaja Rosdakarya. Warni Tune Samar, I. A. R. (2016). Strategi Pembelajaran dan Implementasi Kurikulum Berbasis Soft Skill,. Yogyakarta: Deepublish. 